\title{
PENGEMBANGAN MEDIA KOMIK BERBASIS MASALAH UNTUK PENINGKATAN HASIL BELAJAR IPS SISWA SEKOLAH DASAR
}

\author{
Freddy Widya Ariesta ${ }^{1}$ \\ PGSD Humaniora Bina Nusantara University \\ freddy.ariesta@binus.ac.id \\ Erlina Novi Kusumayati ${ }^{2}$ \\ Pendidikan Dasar Konsentrasi PGSD Universitas Negeri Semarang \\ erlinanovika@gmail.com
}

\begin{abstract}
Based on the results of the analysis of the needs in elementary school at Kalimacan Sragen regency, it is found that the learning result of the students is still low, the learning media used has not cultivated the students' learning interest and the presentation of the less interesting IPS learning materials. This type of research is the Research and Development $(R \& D)$ by Borg \& Gall. Product validation test conducted by a team of experts or an expert assessment, practicality test conducted by questionnaire response after learning of students and teachers, as well as the effectiveness of the test conducted pre-exsperimental design with one group pretest posttest study. The results of this development research that is produced product of comic based media problem that "Valid" with score $82,9 \%$. The practicality of the product in learning is obtained from the result of questionnaire of student and teacher response with score respectively $84,4 \%$ and 86,9\% in "Very Practical" criterion. Retrieved effectiveness of study of the test results is limited by the analysis of $\mathrm{N}$-gain is an increase (gain) learning outcomes Elementary School fourth grade students Kalimacan amounted to 0.651 in the category "Medium". Based on the results of development research conducted, then the development of learning media Social science comic-based problem declared valid, practical and effective to improve student learning outcomes fourth grade elementary school.
\end{abstract}

Keywords: comic media based-problem, social science learning, learning outcomes

\section{ABSTRAK}

Berdasarkan hasil analisis kebutuhan di SD Negeri Kalimacan Kabupaten Sragen, diperoleh temuan bahwa hasil belajar siswa masih rendah, media pembelajaran yang digunakan belum menumbuhkan minat belajar siswa dan penyajian materi pembelajaran IPS yang kurang menarik. Jenis penelitian yang digunakan adalah Penelitian dan Pengembangan (R\&D) menurut Borg \& Gall. Uji validasi produk dilakukan melalui penilaian tim ahli atau pakar, uji kepraktisan dilakukan dengan penyebaran angket respon siswa dan guru setelah pembelajaran, serta uji keefektifan dilakukan secara Pre-exsperimental Design dengan One Group 
Pretest Posttest Study. Hasil penelitian pengembangan ini adalah dihasilkan produk media komik berbasis masalah yang "Valid" dengan skor 82,9\%. Kepraktisan produk dalam pembelajaran diperoleh dari hasil angket respon siswa dan guru dengan skor masing-masing $84,4 \%$ dan $86,9 \%$ dalam kriteria "Sangat Praktis". Diperoleh keefektifan pembelajaran dari hasil uji terbatas melalui analisis $\mathrm{N}$-gain yaitu adanya peningkatan (gain) hasil belajar siswa kelas IV SD Negeri Kalimacan sebesar 0,651 dalam kategori "Sedang". Berdasarkan hasil penelitian pengembangan yang dilakukan, maka pengembangan media pembelajaran IPS komik berbasis masalah dinyatakan valid, praktis dan efektif untuk meningkatkan hasil belajar siswa kelas IV Sekolah Dasar.

Kata Kunci : media komik berbasis masalah, pembelajaran IPS, hasil belajar

\section{A. PENDAHULUAN}

Pembelajaran IPS selalu berkenaan dengan kehidupan manusia yang melibatkan segala macam tingkah laku dan kebutuhannya. Tujuan pembelajaran IPS menurut Sumaatmadja, dalam Hidayati (2008:124) adalah "membina anak didik menjadi warga negara yang baik, yang memiliki pengetahuan, keterampilan, dan kepedulian sosial yang berguna bagi dirinya serta bagi masyarakat dan Negara".

Guru dalam mencapai tujuan pembelajaran IPS harus mampu mendesain dan menggunakan media pembelajaran inovatif yang dapat menumbuhkan keaktifan siswa dalam memahami konsep, pemahaman materi, dan kemampuan siswa dalam memecahkan permasalahan yang diberikan guru, pada akhirnya dapat meningkatkan hasil belajar siswa. Hasil belajar merupakan perubahan perilaku yang diperoleh pembelajar setelah mengalami aktivitas belajar. Menurut Nana Sudjana (2009:3) hasil belajar siswa pada hakikatnya adalah perubahan tingkah laku yang didefinisikan dalam pengertian yang lebih luas mencakup bidang kognitif, afektif, dan psikomotorik

Berdasarkan hasil studi pendahuluan di kelas IV SDN Kalimacan, Kabupaten Sragen, peneliti menemukan beberapa permasalahan yang terjadi dalam pembelajaran IPS antara lain (1) Guru kurang memanfaatkan media pembelajaran, hanya menggunakan buku siswa sebagai sumber belajar; (2) Motivasi belajar siswa masih rendah; (3) Hasil belajar siswa rendah dibuktikan dengan skor nilai rata-rata yang diperoleh siswa secara 
klasikal pada materi IPS yang memenuhi kriteria ketuntasan minimal (KKM) sebesar 67\%. Selain itu, berdasarkan angket pendapat siswa terhadap buku siswa pada materi IPS, diperoleh permasalahan sebagai berikut: 1) Siswa kesulitan memahami buku

siswa secara mandiri; 2) Buku siswa dominan berupa tulisan; 3) Buku siswa kurang menumbuhkan rasa ingin tahu siswa. Dari hal tersebut, dapat disimpulkan bahwa proses pembelajaran kurang menarik dan motivasi belajar yang dimiliki siswa juga masih rendah sehingga hal ini berpengaruh terhadap rendahnya hasil belajar yang diperoleh siswa.

Berdasarkan temuan dalam pembelajaran IPS di atas, kondisi tersebut belum menciptakan pembelajaran yang bermakna karena guru belum mengembangkan media yang mampu memotivasi siswa untuk belajar. Oleh karena itu, perlu diadakan pengembangan media pembelajaran yang sesuai dengan kebutuhan siswa kelas IV sehingga dapat meningkatkan hasil belajarnya.

Melalui pengembangan media pembelajaran IPS berbentuk buku komik berbasis masalah pada tema "Tempat Tinggalku" dapat dijadikan solusi terhadap permasalahan tersebut. Hal ini sesuai dengan pendapat Sudjana (2011:68) yang menyatakan bahwa peranan buku komik dalam pengajaran adalah kemampuannya dalam menciptakan minat baca dan belajar siswa. Selain itu menurut Savery dan Duffy (dalam Savery, 2006:13) menyatakan bahwa motivasi siswa dapat meningkat saat siswa diberi tanggung jawab untuk menyelesaikan masalah. Sementara Duch, Groh, dan Alen (dalam Savery, 2006:13) mengungkapkan bahwa pembelajaran berbasis masalah dapat mengembangkan kemampuan siswa untuk berpikir kritis, menganalisa dan memecahkan masalah konkret, menemukan, serta menunjukkan komunikasi yang efektif menggunakan berbagai keterampilan intelektual agar siswa dapat terus belajar.

Tahap perkembangan anak menurut Piaget, siswa SD kelas IV berada pada tahap operasional konkret (usia 7 hingga 11 tahun). Anak-anak pada tahap ini mengalami kesulitan dengan pemikiran abstrak, berpikiran praktis serta hanya dapat memecahkan masalah yang membumi berdasarkan realitas yang dapat dipahami (Slavin, 2008:51). 
Berdasarkan uraian di atas, media pembelajaran yang tepat adalah media pembelajaran yang disertai dengan ilustrasi, model atau gambar. Media pembelajaran yang disertai dengan ilustrasi, model atau gambar salah satunya adalah media komik. Media komik dapat diartikan sebagai media pembelajaran yang dikemas dalam bentuk cerita bergambar yang dapat menambah kejelasan konsepkonsep dan dapat mengkonstruksi pengetahuan pada siswa (Prastowo, 2012:3).

Implementasi pembelajaran IPS dengan menggunakan media komik pembelajaran berbasis masalah dapat menghubungkan materi pembelajaran dengan informasi yang ada di lingkungan sebenarnya melalui permasalahan yang dimunculkan di dalam komik, sehingga siswa dapat mengkonstruksi pengetahuan sendiri melalui pengalaman belajarnya dalam memecahkan masalah yang sudah disediakan. Ratumanan (2004:45) mengemukakan bahwa teori konstruktivisme didasarkan pada 2 ide utama. Pertama, perkembangan intelektual dapat dipahami hanya bila ditinjau dari konteks historis dan budaya pengalaman anak. Kedua, perkembangan intelektual diciptakan oleh budaya dan belajar untuk menyesuaikan proses-proses berpikir dan membangun pengetahuannya sendiri. Oleh karena itu untuk meningkatkan hasil pembelajaran IPS agar lebih efektif, sumber belajar yang selama ini digunakan oleh guru dapat digabungkan dengan media komik pembelajaran berbasis masalah.

\section{B. LANDASAN TEORI}

\section{Media Komik Berbasis Masalah}

Sudjana dan Rivai (2011:23) mengatakan bahwa komik berfungsi untuk menghibur para pembacanya. Peranan pokok dari buku komik dalam instruksional adalah kemampuannya dalam menciptakan minat siswa (Rohani, 1997:77-79). Dalam penelitian ini, selain untuk menghibur fungsi komik digunakan sebagai media agar siswa termotivasi untuk meningkatkan hasil belajarnya.

Secara garis besar menurut Sungkono dan Eko (dalam Trimo, 1997:37) media pembelajaran komik dibedakan menjadi dua yaitu komik strip (strip comic) dan buku komik (comic book). Komik strip yaitu komik yang berbentuk lembaran-lembaran bingkai kolom yang biasanya bersambung ceritanya. Sedangkan 
yang dimaksud buku komik adalah komik yang berbentuk buku, mempunyai cerita yang lebih panjang, dapat langsung selesai ataupun bisa bersambung. Dalam penelitian ini, yang digunakan berupa media pembelajaran buku komik yang berisi tentang cerita-cerita sederhana untuk mempermudah siswa memahami masalah-masalah konkret dalam masyarakat yang termasuk pada materi tema 8 "Tempat Tinggalku" subtema 3 "Aku bangga dengan daerah tempat tinggalku".

\section{Pembelajaran IPS}

Pembelajaran IPS adalah penyederhanaan atau disiplin ilmuilmu sosial humaniora serta kegiatan dasar manusia yang diorganisasikan dan disajikan secara ilmiah dan pedagogis atau psikologis untuk tujuan pendidikan Winataputra (2007:45). Tujuan pendidikan IPS menurut Hidayati (2008:124) adalah "membina anak didik menjadi warga negara yang baik, yang memiliki pengetahuan, keterampilan, dan kepedulian sosial yang berguna bagi dirinya serta bagi masyarakat dan Negara".

Implementasi pembelajaran IPS di sekolah dasar tidak hanya diarahkan pada pengembangan kompetensi yang berkaitan dengan aspek intelektual saja, namun keterampilan sosial menjadi salah satu faktor penting yang harus dikembangkan sebagai kompetensi yang harus dikuasai oleh siswa dalam pembelajaran IPS.

Berdasarkan teori di atas, untuk mencapai tujuan IPS pada pembelajaran tematik maka guru harus menumbuhkan keaktifan siswa dalam memahami konsep dan pengetahuan yang utuh dengan baik. Siswa yang dapat menguasai konsep dengan baik tidak hanya mampu menghafal sejumlah konsep yang dipelajarinya, namun juga dapat menerapkan pada aspek yang lain dengan cara mengembangkan konsep berpikirnya. Meningkatnya penguasaan konsep, pemahaman materi, dan kemampuan siswa dalam memecahkan permasalahan yang diberikan guru, pada akhirnya dapat meningkatkan hasil belajar siswa.

\section{Hasil Belajar Siswa}

Hasil belajar merupakan perubahan perilaku yang diperoleh pembelajar setelah mengalami aktivitas belajar. Menurut Nana Sudjana (2011:3) hasil belajar siswa pada hakikatnya adalah perubahan 
tingkah laku yang didefinisikan dalam pengertian yang lebih luas mencakup bidang kognitif, afektif, dan psikomotorik.

Sugihartono, dkk. (2007:76), menyebutkan faktor-faktor yang mempengaruhi hasil belajar, meliputi:

(1) Faktor internal, yaitu faktor yang ada dalam diri individu yang sedang belajar, (2) Faktor eksternal yaitu faktor yang ada di luar individu. Salah satu faktor lingkungan belajar yang paling dominan mempengaruhi hasil belajar siswa di sekolah adalah kualitas pengajaran. Kualitas pengajaran adalah tinggi rendahnya atau efektif tidaknya proses belajar mengajar dalam mencapai tujuan pengajaran. Hasil jurnal peneltian (Takari Candra Pramana, 2014) menyatakan bahwa media komik sebagai bahan ajar dapat meningkatkan prestasi belajar siswa kelas IV yang dibuktikan dengan peningkatan nilai rata-rata dan dan sebagian besar telah mencapai kriteria ketuntasan. Berdasarkan faktor-faktor dan hasil penelitian yang mempengaruhi hasil belajar tersebut, peneliti menggunakan faktor eksternal berupa penggunaan media komik berbasis masalah yang diterapkan pada pembelajaran IPS untuk meningkatkan hasil belajar siswa.

\section{METODE PENELITIAN}

Jenis dan desain penelitian yang digunakan adalah Education Research and Development (R\&D). Penelitian ini mengembangkan media pembelajaran IPS komik berbasis masalah untuk meningkatkan hasil belajar siswa. Penelitian ini dilakukan penyederhanaan sepuluh langkah penelitian dan pengembangan menurut Borg \& Gall (1981:792) menjadi 7 langkah. Penyerderhanaan ini sesuai dengan yang dikemukakan oleh (Sukmadinata, 2005:169-170) yaitu: (1) penelitian dan pengumpulan data, (2) melakukan perencanaan, (3) pengembangan draf produk, (4) uji coba lapangan awal, (5) merevisi hasil uji coba, (6) uji coba lapangan utama, dan (7) penyempurnaan produk hasil uji lapangan. Rancangan uji coba terbatas dilakukan secara Pre-exsperimental Design dengan One Group Pretest Posttest Study. Siswa diberi pretest sebelum perlakuan kemudian diberikan posttest sesudah pembelajaran menggunakan media komik yang dikembangkan terhadap hasil belajar siswa. 
Kelas Eksperimen

$\mathrm{O}_{1}$

$X_{1}$

$\mathrm{O}_{2}$

Gambar 1. Rancangan Ujicoba

Terbatas menggunakan One Group

Pretest Posttest Study

Uji coba terbatas digunakan untuk memperoleh keefektifan dan kepraktisan media komik berbasis masalah diimplementasikan dalam pembelajaran IPS. Peneliti melakukan teknik pengumpulan data dengan cara observasi, wawancara, dan angket yang berpedoman pada instrument yang dibuat dan dikembangkan sendiri oleh peneliti.

Analisis kevalidan produk, data diperoleh dari angket validasi yang diberikan kepada para ahli materi dan ahli media yang memberikan penilaian terhadap media pembelajaran IPS komik berbasis masalah yang dikembangkan. Media komik berbasis masalah yang telah divalidasi kemudian data dianalisis dengan menggunakan teknik analisis deskriptif persentase. Data yang tertera pada lembar validasi merupakan penilaian dari masingmasing validator terhadap media komik berbasis masalah dianalisis berdasarkan rata-rata skor.
Tabel 1. Kriteria Kevalidan

\begin{tabular}{ll}
\hline Persentase (\%) & Kategori \\
\hline $81-100$ & Sangat Valid \\
$61-80$ & Valid \\
$41-60$ & Cukup Valid \\
$21-40$ & Tidak Valid \\
$1-20$ & Sangat Tidak Valid \\
\hline
\end{tabular}

Tabel 1 adalah kriteria skor kevalidan media komik berbasis masalah, dimana skor diperoleh dari rata-rata hasil penilaian validator. Kriteria media komik berbasis masalah dikatakan valid jika rata-rata skor $\geq 80 \%$ atau berada pada kategori minimal valid.

Pengujian keefektifan produk media komik berbasis masalah yang dikembangkan di uji peningkatan hasil belajar dianalisis menggunakan uji N-Gain yang didasarkan dari nilai pretest dan postest. Adapun rumus yang digunakan yaitu:

$$
(g)=\frac{S_{\text {post }}-S_{\text {pre }}}{S_{\max }-S_{p X X e}}
$$

(Hake, 1998)

Kriteria perolehan $n$-gain adalah sebagai berikut:

$0,0 \leq(\mathrm{g})<0,3=$ Rendah

$0,3 \leq(\mathrm{g})<0,7=$ Sedang

$0,7 \leq(\mathrm{g})<1,0=$ Tinggi

Hasil belajar siswa dikatakan meningkat jika perolehan gain ternormalisasi tergolong pada kriteria minimal sedang atau 0,3 $\leq(\mathrm{g})<0,7$. 
Pengujian kepraktisan dilakukan penyebaran angket yang di dalamnya terdapat 14 pertanyaan mengenai media pembelajaran IPS komik berbasis masalah yang dikembangkan dan diisi oleh siswa dan guru sesudah pembelajaran, masing-masing aspek pertanyaan diberikan skor 1, 2, 3, dan 4 kemudian data dianalisis secara deskriptif persentase.

Tabel 2. Kriteria Kepraktisan

\begin{tabular}{ll}
\hline Persentase (\%) & Kategori \\
\hline $81-100$ & Sangat Praktis \\
$61-80$ & Praktis \\
$41-60$ & Cukup Praktis \\
$21-40$ & Tidak Praktis \\
$1-20$ & Sangat Tidak Praktis \\
\hline
\end{tabular}

Tabel 2 adalah kriteria skor kepraktisan media komik berbasis masalah, dimana skor diperoleh dari angket respon guru dan respon siswa terhadap media pembelajaran IPS komik berbasis masalah. Kriteria media komik berbasis masalah dikatakan praktis jika rata-rata skor $\geq$ $80 \%$ atau kategori minimal praktis.

\section{HASIL DAN PEMBAHASAN}

\section{Karakteristik Media Komik Berbasis Masalah}

Produk media Pembelajaran IPS komik berbasis masalah yang dikembangkan adalah pada materi kelas IV SD tema 8 "Tempat Tinggalku" sub tema 3 "Aku Bangga Dengan Daerah Tempat Tinggalku" mempunyai karakteristik yang terdiri dari 3 aspek yaitu: 1) kualitas isi dan tujuan pembelajaran meliputi: dari identitas buku, kata pengantar, daftar isi, petunjuk penggunaan komik, tokoh komik, 6 sub materi pokok, soal evaluasi dan biomini yang sesuai dengan tujuan pembelajaran, 2) kualitas instruksional meliputi: kemampuan meningkatkan motivasi belajar dan tes evaluasi, 3) kualitas teknis meliputi: ukuran kertas, pewarnaan dan karakter tokoh. Menurut Arsyad (2005:175-176) bahwa komik sebagai media pembelajaran yang baik jika memenuhi kualitas isi dan tujuan yang jelas meliputi format isi komik dan isi materi komik.

Isi materi komik dalam setiap pertemuan memuat materi yang berbeda, dengan konsep pembelajaran berbasis masalah yang membahas berbagai permasalahan faktual yang akan mereka temukan di lingkungan sekitar, sehingga siswa akan mengembangkan kemampuan intelektualnya untuk membentuk budaya berpikir dan membangun pengetahuannya (konstruktivisme) 
Pendas : Jurnal IImiah Pendidikan Dasar, ISSN Cetak : 2477-2143 ISSN Online : 2548-6950

Volume III Nomor 1, Juni 2018

berdasarkan pengalaman yang diperoleh dan dipelajari. Hal tersebut sesuai pendapat Ratumanan (2004:45) mengemukakan bahwa teori konstruktivisme didasarkan pada dua hal. Pertama, perkembangan intelektual dapat diperoleh dari pengalaman anak. Kedua, perkembangan intelektual diciptakan oleh budaya belajar siswa untuk menyesuaikan proses berpikir dan membangun pengetahuannya sendiri.

\section{Kevalidan Media Komik Berbasis}

\section{Masalah}

Kevalidan media komik berbasis masalah diperoleh melalui penilaian tiga validator, yaitu dua validator ahli materi dan satu validator ahli media. Kevalidan materi media komik berbasis masalah yang dikembangkan dinilai dari tiga aspek yaitu: 1) aspek format pembelajaran; 2) aspek isi materi; dan 3) aspek bahasa. Hasil penilaian dari validator ahli materi I dan II diperoleh total skor validasi 77 atau $80,2 \%$ sehingga dalam kriteria "Valid". Terkait rekapitulasi skor penilaian ahli materi pada komik berbasis masalah dapat dilihat pada Tabel 3 Berikut.
Tabel 3. Rekapitulasi Skor Validasi

Ahli Materi

\begin{tabular}{|c|c|c|c|c|}
\hline \multirow[t]{2}{*}{ No } & \multirow{2}{*}{$\begin{array}{l}\text { Aspek yang } \\
\text { Dinilai }\end{array}$} & \multicolumn{2}{|c|}{ Validator } & \multirow[t]{2}{*}{ Total } \\
\hline & & I & II & \\
\hline 1 & Format & & & \\
\hline \multirow{2}{*}{$\begin{array}{l}2 \\
3\end{array}$} & Pembelajaran & 12 & 13 & 25 \\
\hline & $\begin{array}{l}\text { Isi Materi } \\
\text { Bahasa }\end{array}$ & $\begin{array}{l}12 \\
12\end{array}$ & 13 & 25 \\
\hline \multicolumn{2}{|c|}{ Jumlah Skor } & 37 & 40 & 77 \\
\hline \multirow{2}{*}{\multicolumn{2}{|c|}{$\begin{array}{l}\text { Skor maksimal } \\
\text { Persentase\% }\end{array}$}} & \multicolumn{2}{|c|}{48} & 96 \\
\hline & & 77,1 & 83,3 & 80,2 \\
\hline
\end{tabular}

media komik berbasis masalah yang dikembangkan dinilai dari tiga aspek yaitu: 1) aspek tampilan komik; 2) aspek bahan komik; 3) aspek komunikasi visual. Hasil penilaian dari validator ahli media pada pengembangan media pembelajaran IPS komik berbasis masalah berdasarkan tiga aspek yang dinilai, maka diperoleh total skor validasi 48 atau $85,7 \%$ sehingga dalam kriteria "Sangat Valid". Terkait rekapitulasi skor penilaian ahli media pada komik berbasis masalah dapat dilihat pada Tabel 4 Berikut.

Tabel 4. Rekapitulasi Skor Validasi Ahli Media

\begin{tabular}{llcc}
\hline \multirow{2}{*}{ No } & $\begin{array}{l}\text { Aspek yang } \\
\text { Dinilai }\end{array}$ & \begin{tabular}{c} 
Validator \\
\cline { 2 - 3 }
\end{tabular} & Total \\
\hline 1 & Tampilan Komik & 24 & 24 \\
2 & Bahan Komik & 15 & 25 \\
3 & Bahasa Komik & 9 & 9 \\
\hline Jumlah Skor & 48 & 48 \\
\hline Skor maksimal & 56 & 56 \\
\hline Persentase\% & 85,7 & 85,7 \\
\hline
\end{tabular}


Data uji kepraktisan diperoleh melalui angket respon siswa dan guru, kemudian dianalisis dengan tujuan untuk menguji apakah produk pengembangan media komik berbasis masalah pada pembelajaran tematik kelas IV Sekolah Dasar sudah praktis dan mudah dalam pemakaiannya atau belum. Diperoleh rata-rata skor angket respon siswa sebesar 35,5 atau $84,4 \%$, dalam kategori "Sangat Praktis". Adapun rata-rata skor respon angket guru diperoleh 5,2 atau $86,9 \%$. Sehingga media pembelajaran IPS komik berbasis masalah berdasarkan data angket guru tersebut dalam kategori "Sangat Praktis.

\section{Keefektifan Hasil Belajar Siswa}

Data keefektifan hasil belajar diperoleh dari skor pretest dan posttest kognitif siswa pada pembelajaran tematik menggunakan media pembelajaran IPS komik berbasis masalah. Berdasarkan data pretest-posttest yang telah dilakukan saat uji coba, maka diperoleh data kemudian dianalisis dengan $n$-gain untuk mengetahui peningkatan kemampuan hasil belajar siswa.
Tabel 5. Data Penigkatan (N-Gain) Kelas Uji Coba

\begin{tabular}{lcc}
\hline \multicolumn{1}{c}{ Skor } & $\begin{array}{c}\text { Data } \\
\text { Pretest }\end{array}$ & $\begin{array}{c}\text { Data } \\
\text { Posttest }\end{array}$ \\
\hline Jumlah Siswa & 24 & 24 \\
Skor Terendah & 46 & 56 \\
Skor Tertinggi & 94 & 100 \\
Skor Maksimal & 100 & 100 \\
Rentang (R) & 48 & 44 \\
Rata-rata & 70,22 & 81,66 \\
\hline Peningkatan (gain) & \multicolumn{2}{c}{$\mathbf{0 , 6 5 1}$} \\
\hline Kriteria & \multicolumn{2}{c}{ Sedang } \\
\hline
\end{tabular}

Berdasarkan hasil analisis pada Tabel 5 terlihat bahwa ada peningkatan kemampuan kognitif siswa pada pembelajaran tematik kelas IV Sekolah Dasar menggunakan media pembelajaran IPS komik berbasis masalah. Peningkatan (gain) pada siswa kelas uji coba diperoleh rata-rata indeks gain sebesar 0,651. Berdasarkan kriteria interpretasi indeks gain yang dikemukakan oleh Hake (1998), maka indeks (gain) tersebut pada kriteria "Sedang". Menurut Mulyasa (2007:254) hasil belajar siswa dikatakan meningkat jika perolehan gain ternormalisasi tergolong pada kriteria minimal sedang atau 0,3 $\leq(\mathrm{g})$ $<0,7$. Sedangkan, untuk rekapitulasi hasil perhitungan uji peningkatan (gain) kelas uji coba berdasarkan nilai posttest dan pretest dapat dilihat pada Tabel 6. 
Tabel 6. Rekapitulasi Uji N Gain Kelas Uji Coba

\begin{tabular}{lccc} 
Kelas & \multicolumn{3}{c}{ Uji Coba } \\
\hline Kriteria & Rendah & Sedang & Tinggi \\
Jumlah Siswa & 7 & 11 & 6 \\
Persentase (\%) & $29 \%$ & $46 \%$ & $25 \%$
\end{tabular}

Berdasarkan pada Tabel 6 terlihat bahwa ada peningkatan kognitif siswa dengan kategori rendah sebanyak 7 siswa atau sebesar $29 \%$, nilai skor siswa yang mengalami peningkatan dalam kategori sedang sebanyak 11 siswa atau sebesar $46 \%$ dan nilai skor siswa yang mengalami peningkatan dalam kategori tinggi sebanyak 6 siswa atau sebesar $25 \%$.

\section{E. KESIMPULAN}

Simpulan hasil penelitian adalah sebagai berikut: (1) Dihasilkan media pembelajaran IPS komik berbasis masalah pada materi kelas IV SD tema 8 "Tempat Tinggalku" sub tema 3 "Aku Bangga Dengan Daerah Tempat Tinggalku" yang terdiri dari identitas buku, kata pengantar, daftar isi, petunjuk penggunaan komik, tokoh komik, 6 sub materi pokok, soal evaluasi dan biomini. (2) Dihasilkan media pembelajaran IPS komik berbasis masalah yang valid dengan jumlah rata-rata skor validasi ahli materi dan ahli media sebesar 82,9\%.

(3) Hasil respons guru terhadap terhadap media pembelajaran IPS komik berbasis masalah diperoleh skor persentase $87 \%$ dengan kriteria "Sangat Praktis". Adapun hasil respons siswa diperoleh skor persentase $84 \%$ dengan kriteria "Sangat Praktis". (4) Diperoleh peningkatan nilai hasil belajar siswa kelas IV Sekolah Dasar pada pembelajaran IPS menggunakan media komik berbasis masalah dengan analisis uji $\mathrm{N}$-Gain sebesar 0,651 dengan kriteria "Sedang".

Saran dari hasil penelitian yaitu: (1) media komik berbasis masalah telah terbukti valid sehingga dapat digunakan guru sebagai salah satu alternatif media pembelajaran untuk meningkatkan hasil belajar siswa Sekolah Dasar, (2) hasil produk penelitian ini dapat dijadikan referensi bagi guru untuk mengembangkan media pembelajaran lain yang dapat meningkatkan hasil belajar siswa Sekolah Dasar.

\section{DAFTAR PUSTAKA}

Arsyad, Azhar. 2005. Media Pembelajaran. Jakarta: Raja Grafindo Persada.

Borg and Gall. 1981. Educational Research, An Introduction. New York and London. Longman Inc. 
Botzakis, S. 2009. "Adult Fans of Comic Books: What They Get Out of Reading". Journal of Adolescent \& Adult Literacy, Volume 53 No. 1. Hal 50-59.

Hake R. 1998. Analyzing ChangeGain Scores. USA: Dept. of Physics, Indiana University.

Hidayati. 2008. Pengembangan Pendidikan IPS SD. Jakarta: Dirjendikti Depdiknas.

Mulyasa, E. 2007. Menjadi Guru Profesional Menciptakan Pembelajaran Kreatif dan Menyenangkan. Bandung:

Rosdakarya

Prastowo, A. 2012. Panduan Kreatif Membuat Bahan Ajar Inovatif. Jogjakarta: Diva Press.

Prastowo, A. 2012. Panduan Kreatif Membuat Bahan Ajar Inovatif. Jogjakarta: Diva Press.

Ratumanan. $2004 . \quad$ Model

Pembelajaran Menciptakan

Proses Belajar Mengajar yang Kreatif dan Efektif. Jakarta:

Bumi Aksara.

Robert E. Slavin. 2008. Cooperative Learning Teori, Riset dan Praktik. Bandung: Nusa Media. Rohani, Ahmad. 2007. Media Instruksional Edukatif. Jakarta: Rineka Cipta.
Savery J.R. 2006. Overview of Problem-based Learning: Definitions and Distinctions. Interdisciplinary Journal of Problem-Based Learning, 1(1). pp. 7-11.

Sudjana, N, dan Rivai, A. 2011. Media Pengajaran. Bandung: Sinar Baru Algesindo.

Sudjana, Nana. 2009. Penilaian Hasil Proses Belajar Mengajar. Bandung: Remaja Rosdakarya.

Sugiyono. 2007. Metode Penelitian Pendidikan.Bandung: Alfabeta. Sukmadinata, Nana Syaodih. 2005. Metode Penelitian Pendidikan. Bandung: Rosdakarya.

Takari Candra P. 2014. Pengembangan Media Komik Sebagai Bahan Ajar IPA Materi Hubungan Sumber Daya Alam Dengan Lingkungan Pada Siswa Kelas IV SD. Thesis. Yogyakarta: Universitas PGRI Yogyakarta.

Trimo.1997. Media Pendidikan. Jakarta: Depdikbud.

Udin S, Winataputra dkk. 2007. Materi dan pembelajaran IPS SD. Jakarta: Universitas Terbuka. 